\title{
Valorization of roasted longan stone in production of functional biscuits with high antioxidant activity and dietary fiber
}

\author{
Sibel BÖLEK ${ }^{1 *}$ (D)
}

\begin{abstract}
Being waste products of the food industry, longan stones can be a promising functional food ingredient owing to their high fiber content, nutrients and antioxidative properties. Biscuits were enriched with roasted and unroasted longan stone powder. The longan stones were roasted at $170{ }^{\circ} \mathrm{C}$ for 5,15 , and $25 \mathrm{~min}$ by using a fluidized bed roaster. Longan stone powders were incorporated in wheat flours at different concentrations. Biscuits were obtained with higher fiber content (5.72 $\pm 0.03 \%)$ and lower fat content $(12.50 \pm 0.02 \%)$ compared to the control biscuits. Antioxidant activity $(51.18 \pm 0.02 \%$ inhibition $)$ and total phenolic contents $(394.61 \pm 0.63 \mathrm{mg} \mathrm{GAE} / 100 \mathrm{~g}$ ) of the biscuits increased significantly as the roasting degree of added longan stone powder increased $(\mathrm{p} \leq 0.05)$. Biscuits enriched with longan stone powder roasted during 15 minutes took higher sensory scores than control biscuits and biscuits enriched with unroasted longan stone powder. The roasting process increased the acceptability of addition longan stone powder.
\end{abstract}

Keywords: longan stone; roasting; fiber; antioxidant activity; sensory.

Practical Application: Thanks to their long shelf life, cheapness and general acceptability, the biscuits are very popular snack foods among all age groups in many countries. On the other hand, they lack several nutrients, including some minerals, vitamins, protein, and fiber. Thanks to its high antioxidant activity, fiber and protein contents, longan stone powder can improves the nutritional value of biscuits.

\section{Introduction}

In recent years, the worldwide trend towards functional foods has been notable. Demand for health oriented bakery products with high antioxidant activity, fiber and, protein content is increasing because bakery products are consumed all over the world among all age groups. Since enriched products may contribute to improving digestive, intestinal and immune systems by reducing risks of cancer, lowering cholesterol, preventing osteoporosis, coroner health diseases and type-2 diabetes, these products provide a healthier appeal to the consumer (Lin et al., 2016). Thus, many enriched product formulations have been developed.

Longan (Dimocarpus longan Lour.) is a non-climacteric subtropical fruit (Shi et al., 2013) and it has a very high commercial value. The longan aril and stones have anti-tyrosinase, anticancer and, anti-glycated and activities (Rangkadilok et al., 2007; Yang et al., 2011). Longan stone accounts for about $17 \%$ of the whole fruit on wet basis (Jiang et al., 2013). The stones of longan are an excellent source of vitamin, minerals, protein, and dietary fiber (Li et al., 2012). Stones are waste products of many industries and they are also evaluated as animal feed, poultry and the soil fertilizers. Valorization of waste of food products is very important in regard to the circular economy context. Since longan stones are an excellent source of fiber, antioxidants, and phenolics, they can be a promising functional food ingredient in different industries (Zheng et al., 2009). In addition, longan stone contains gallic acid and ellagic acid (Soong \& Barlow, 2006).
Roasting is the most essential part of many foods items processing. Roasting is responsible for desired aroma and flavor components. Antioxidative compounds of different food materials increase with the roasting process (Choi et al., 2012). Since roasting is crucial, many roasting methods and devices have been developed to achieve desired results.

Thanks to their long shelf life, cheapness and general acceptability, the biscuits are very popular among all age groups in many countries. On the other hand, they lack several nutrients, including some minerals, vitamins, protein, and fiber. Thanks to its high antioxidant activity, fiber and protein contents, longan stone powder can improves the nutritional value of biscuits. However, no study has been done so far to fortify the biscuits with longan stone powder. Furthermore, no work has been investigated the effects of roasting process on longan stone. Therefore, the main purpose of this study was to investigate the possibility of enriching biscuits with fluidized bed roasted longan stone powder as a ready to eat snack and good eating quality.

\section{Materials and methods}

\subsection{Materials}

Ingredients of biscuit dough purchased from a commercial market in Maltepe, İstanbul, Turkey. 
Longan fruits were purchased from Antalya, Turkey in September 2019. Longan stones were removed from the fruit manually and kept at $-18^{\circ} \mathrm{C}$ until further analysis.

All chemicals used were of either higher available purity or analytical grade.

\subsection{Longan stone powder preparation}

Longan stones were cleaned in hot water $\left(50^{\circ} \mathrm{C}\right)$ to discard any adhering fruit flesh then roasted by a fluidized bed roaster (Toper Optical 001 , Turkey) at $170{ }^{\circ} \mathrm{C}$ for 5,15 , and $25 \mathrm{~min}$. The longan stones were ground by a grinder (Pulverisette 14, Fritsch, Germany), which is equipped with a sieve system, with a particle size of $150 \mu \mathrm{m}$.

\subsection{Biscuit formulation and preparation}

Biscuit samples were prepared according to the AACC Method No. 10-54 (American Association of Cereal Chemists, 2000). Biscuit dough was prepared with $100 \mathrm{~g}$ commercial soft type 500 (ash $0.53 \mathrm{~g} / 100 \mathrm{~g}$, moisture content $14.03 \mathrm{~g} / 100 \mathrm{~g}$ ) wheat flour (Söke flour, Tukey) $30 \mathrm{~g}$ sugar (Balküpü sugar, Turkey), $10 \mathrm{~g}$ butter (İçim butter, Turkey), $2.0 \mathrm{~g}$ skim milk powder (Pınar milk powder, Turkey), $1.0 \mathrm{~g}$ ammonium bicarbonate (Merck, Germany), $1.0 \mathrm{~g}$ lecithin (Merck, Germany), $1.0 \mathrm{~g}$ sodium chloride (Merck, Germany), $0.5 \mathrm{~g}$ sodium bicarbonate (Merck, Germany), $0.3 \mathrm{~g}$ salt (Billur salt, Turkey) and deionized water $(20 \mathrm{~mL})$. All ingredients were mixed in a dough mixer using a homogenizer (KitchenAid, Artisan 5KSM175PSEER) for four $\mathrm{min}$ at $85 \mathrm{rpm}$ and for three min at $160 \mathrm{rpm}$ and kneaded by hand for $2 \mathrm{~min}$. Biscuits were baked at $180 \pm 2.0^{\circ} \mathrm{C}$ for $15 \mathrm{~min}$ by an electrical oven. After baking, the biscuits were cooled and packed into double high density polyethylene bags for further analysis. Biscuit-making was carried out in triplicate.

\subsection{Proximate analysis}

The proximate analysis of longan stone and biscuits were determined according to the method of Association of Official Analytical Chemists (2005).

\subsection{Color measurements}

The $\mathrm{L}^{*}, \mathrm{a}^{*}, \mathrm{~b}^{\star}$ values of biscuits were determined using a chroma meter (model CR-400, Konica Minolta Inc., Osaka, Japan). The calibration was performed with standard black and white tile before analysis.

\subsection{Extract preparation}

One gram of biscuit sample was extracted with $40 \mathrm{~mL}$ $0.16 \mathrm{~mol} / \mathrm{L} \mathrm{HCl}$ in $80 \mathrm{~mL} / 100 \mathrm{~mL}$ methanol for $2 \mathrm{~h}$ in a water bath (Daihan, WUC-D10H, South Korea). The obtained extract was separated in a centrifuge (Sigma 3-30KS, Germany) at $4500 \mathrm{rpm}$ for $15 \mathrm{~min}$ and solvent was removed using a rotary evaporator (Laborota 4000, Heidolph, Germany) under reduced pressure.

\subsection{Total phenolic content measurements}

The total phenolic contents of biscuits were measured using Folin and Ciocalteu assay (Slinkard \& Singleton, 1977). Briefly, $0.5 \mathrm{~mL}$ methanolic extract was mixed with $2.5 \mathrm{~mL}$ of $10 \%$ Folin-Ciocalteu reagent. Then, $2.5 \mathrm{~mL}$ of sodium carbonate $(7.5 \%, \mathrm{w} / \mathrm{v})$ was added. The mixture incubated at dark for $45 \mathrm{~min}$. The absorbance of the standard (gallic acid) and the extract of biscuit samples was determined spectrophotometrically at $765 \mathrm{~nm}$ against blank.

\subsection{Antioxidant activity (DPPH) assay}

Antioxidant activity was stated by DPPH radical assay according to the method of Cuendet et al. (1997) with some modifications. Briefly, $0.5 \mathrm{~mL}$ of $0.1 \mathrm{mM} \mathrm{DPPH}$ in methanol was mixed with $0.5 \mathrm{~mL}$ of the sample in a test tube. Then, the mixture was shaken for $2 \mathrm{~min}$ and incubated at dark for $30 \mathrm{~min}$. The absorbance of each sample solution was determined at $515 \mathrm{~nm}$. The following Equation 1 was used to calculation of DPPH radical scavenging activity:

DPPH Scavenging Activity $(\%)=\frac{A_{\text {Control }}-A_{\text {sample }}}{A_{\text {Control }}} \times 100$

\subsection{Determination of textural characteristics of biscuits}

Fracturability and hardness values of the biscuits were determined using a Texture Analyzer TA.XT plus (Stable Micro Systems, England) with $50 \mathrm{~kg}$ load cell. Fracturability was determined by 3-point bending based on the method of Baljeet et al. (2010). The pre-test speed, test speed and post-test speed were $0.1 \mathrm{~mm} / \mathrm{s}, 0.2 \mathrm{~mm} / \mathrm{s}$, and $0.1 \mathrm{~mm} / \mathrm{s}$, respectively. Hardness of biscuit samples were determined by $2 \mathrm{~mm}$ cylinder. The pre-test speed, test speed and post-test speed were $0.1 \mathrm{~mm} / \mathrm{s}$, $0.2 \mathrm{~mm} / \mathrm{s}$, and $0.5 \mathrm{~mm} / \mathrm{s}$ respectively.

\subsection{Sensory analysis}

120 panelists (53 male and 67 females) evaluated the sensory properties of biscuit samples based on ISO 8586 (International Organization for Standardization, 2012). Five different sensory properties of biscuits were determined by using a 5-point hedonic scale. The biscuits were served to the panelist according to the norm ISO 8589 (International Organization for Standardization, 2007). The biscuits were tested by evaluating appearance first, then odor, texture and flavor, and finally, overall impression. The sensory test received favorable opinion by the Research Ethics Committee on 22 October 2020.

\subsection{Statistical analysis}

The study was performed by completely randomized design with 3 replications. All data were expressed as mean values \pm SD. Analysis of variance using PROC GLM of the SAS system (version 8.01, SAS Institute, Cary, NC) followed by Duncan's Multiple Range test at the level of 5\% being considered statistically significantly (SAS Institute Inc., 1999). 


\section{Results and discussion}

\subsection{Proximate compositions of unroasted and fluidized bed roasted longan stone powders}

The proximate compositions of unroasted and fluidized bed roasted longan stone powders are shown in Table 1. As the roasting degree increased, the moisture content of longan stone powders decreased significantly $(\mathrm{p} \leq 0.05)$. This was probably due to the dehydration of longan stones during roasting. While the reduction in the moisture content of longan stone was less notable at the final stages of roasting, it was high in the initial stages of roasting.

The total protein content of longan stone powders decreased non-significantly during roasting $(\mathrm{p}>0.05)$. The results presented in this work are compatible with the findings of De Maria et al. (1996) who stated that protein content of Arabica coffee beans decreased during roasting slightly.

The roasting process had no significant effect on crude fiber content ( $p>0.05)$. Supporting results were obtained in the study which investigated the effects on roasting on fiber contents of cocoa beans (Valiente et al., 1994).
The fat content of longan stone powders non-significantly ( $p>0.05$ ) increased during roasting.

The ash content of longan stone powders non-significantly ( $>0.05)$ decreased during roasting. Similar results were obtained for ash content of roasted defective coffee beans (Oliveira et al., 2006).

Antioxidant activity and total phenolic content of longan stone powders increased significantly during roasting $(\mathrm{p} \leq 0.05)$ by reaching an apparent maximum at $170{ }^{\circ} \mathrm{C}$ for $15 \mathrm{~min}$. There was a significant decrease in the antioxidant capacity and total phenolic content after a roasting time of $25 \mathrm{~min}$. The behavior of antioxidant activity and total phenolic content of longan stone powder could be attributed to the importance of novel antioxidant substances formed during the roasting process, such as Maillard reaction products, which are lost or undergone pyrolysis when the roasting proceeds under more severe conditions (Priftis et al., 2015).

\subsection{Proximate composition of biscuits}

The proximate compositions of biscuits are shown in Table 2. The moisture content of biscuit samples increased significantly as the increasing replacement ratio of longan stone powder

Table 1. Proximate Composition of Unroasted and Fluidized Bed Roasted Longan Stones.

\begin{tabular}{|c|c|c|c|c|}
\hline & \multirow{2}{*}{ Unroasted } & Roasted & Roasted & Roasted \\
\hline & & $\left(170^{\circ} \mathrm{C}, 5 \mathrm{~min}\right)$ & $\left(170^{\circ} \mathrm{C}, 15 \mathrm{~min}\right)$ & $\left(170^{\circ} \mathrm{C}, 25 \mathrm{~min}\right)$ \\
\hline Moisture (g.100g-1) (dwb) & $4.32 \pm 0.04^{\mathrm{a}}$ & $3.35 \pm 0.02^{\mathrm{b}}$ & $2.54 \pm 0.01^{\mathrm{c}}$ & $1.90 \pm 0.03^{\mathrm{d}}$ \\
\hline Total protein $\left(\mathrm{g} \cdot 100 \mathrm{~g}^{-1}\right)(\mathrm{dwb})$ & $5.48 \pm 0.07^{\mathrm{a}}$ & $5.33 \pm 0.01^{\mathrm{a}}$ & $5.17 \pm 0.04^{\mathrm{a}}$ & $5.10 \pm 0.02^{\mathrm{a}}$ \\
\hline 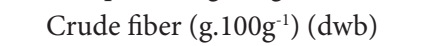 & $6.10 \pm 0.05^{\mathrm{a}}$ & $6.02 \pm 0.03^{\mathrm{a}}$ & $5.93 \pm 0.03^{\mathrm{a}}$ & $5.88 \pm 0.04^{\mathrm{a}}$ \\
\hline Fat $\left(\mathrm{g} .100 \mathrm{~g}^{-1}\right)(\mathrm{dwb})$ & $2.42 \pm 0.07^{\mathrm{a}}$ & $2.47 \pm 0.02^{\mathrm{a}}$ & $2.52 \pm 0.05^{\mathrm{a}}$ & $2.56 \pm 0.04^{\mathrm{a}}$ \\
\hline $\operatorname{Ash}\left(\mathrm{g} \cdot 100 \mathrm{~g}^{-1}\right)(\mathrm{dwb})$ & $1.11 \pm 0.01^{\mathrm{a}}$ & $1.10 \pm 0.03^{\mathrm{a}}$ & $1.08 \pm 0.02^{\mathrm{a}}$ & $1.06 \pm 0.01^{\mathrm{a}}$ \\
\hline \multicolumn{5}{|l|}{ Total Phenolic } \\
\hline Content (mg GAE/g.100g-1) (dwb) & $6058.06 \pm 0.18^{\mathrm{a}}$ & $6212 \pm 0.13^{\mathrm{b}}$ & $6352 \pm 0.16^{c}$ & $6240 \pm 0.12^{\mathrm{b}}$ \\
\hline Antioxidant activity (Inhibition \%) & $52 \pm 0.02^{\mathrm{a}}$ & $61 \pm 0.02^{\mathrm{b}}$ & $73 \pm 0.02^{c}$ & $66 \pm 0.02^{b}$ \\
\hline
\end{tabular}

Values are mean \pm standard deviation of three separate determinations $(\mathrm{n}=3)$. Values in the row with the same letter in superscript are not significant different from each other at $\mathrm{p} \leq 0.5$.

Table 2. Proximate Composition and Antioxidative Properties of Biscuit Samples

\begin{tabular}{|c|c|c|c|c|c|c|c|}
\hline $\begin{array}{l}\text { Substitution } \\
\text { ratio/roasting } \\
\text { time }\end{array}$ & $\begin{array}{l}\text { Moisture Content } \\
\left(\mathrm{g} \cdot 100 \mathrm{~g}^{-1}\right)(\mathrm{dwb})\end{array}$ & $\begin{array}{l}\text { Total Protein } \\
\left(\mathrm{g} .100 \mathrm{~g}^{-1}\right)(\mathrm{dwb})\end{array}$ & 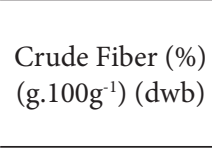 & 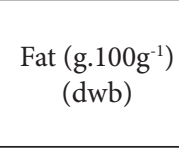 & $\begin{array}{c}\text { Ash }\left(\mathrm{g} .100 \mathrm{~g}^{-1}\right) \\
(\mathrm{dwb})\end{array}$ & $\begin{array}{c}\text { Total Phenolic } \\
\text { Content } \\
\text { (mg GAE/g.100g-1) } \\
(\mathrm{dwb})\end{array}$ & $\begin{array}{c}\text { Antioxidant } \\
\text { Activity } \\
\text { Inhibition } \\
\left(\mathrm{g} .100 \mathrm{~g}^{-1}\right)(\mathrm{dwb})\end{array}$ \\
\hline $\mathrm{T}_{0}$ & $2.48 \pm 0.04^{\mathrm{d}}$ & $10.20 \pm 0.02^{\mathrm{d}}$ & $0.91 \pm 0.01^{\mathrm{d}}$ & $20.66 \pm 0.02^{\mathrm{a}}$ & $1.98 \pm 0.01^{\mathrm{a}}$ & $155.06 \pm 0.41^{\mathrm{j}}$ & $5.80 \pm 0.01^{\mathrm{i}}$ \\
\hline $\mathrm{T}_{5,0}$ & $3.50 \pm 0.02^{c}$ & $11.16 \pm 0.01^{\mathrm{c}}$ & $3.30 \pm 0.03^{c}$ & $16.72 \pm 0.01^{\mathrm{b}}$ & $1.92 \pm 0.01^{\mathrm{a}}$ & $192.22 \pm 0.72^{\mathrm{i}}$ & $18.85 \pm 0.02^{\mathrm{h}}$ \\
\hline $\mathrm{T}_{5,5}$ & $3.30 \pm 0.02^{c, d}$ & $11.12 \pm 0.01^{\mathrm{c}}$ & $3.28 \pm 0.03^{c}$ & $16.85 \pm 0.02^{\mathrm{b}}$ & $1.90 \pm 0.01^{\mathrm{a}}$ & $205.81 \pm 0.24^{\mathrm{h}}$ & $22.32 \pm 0.02^{\mathrm{g}}$ \\
\hline $\mathrm{T}_{5,15}$ & $3.22 \pm 0.03^{c, d}$ & $11.08 \pm 0.02^{c}$ & $3.25 \pm 0.01^{c}$ & $17.02 \pm 0.01^{\mathrm{b}}$ & $1.87 \pm 0.01^{\mathrm{a}}$ & $224.22 \pm 0.62^{\mathrm{g}}$ & $27.18 \pm 0.01^{\mathrm{f}}$ \\
\hline $\mathrm{T}_{5,25}$ & $3.18 \pm 0.01^{\mathrm{c}, \mathrm{d}}$ & $11.03 \pm 0.04^{\mathrm{c}}$ & $3.22 \pm 0.02^{c}$ & $17.25 \pm 0.01^{\mathrm{b}}$ & $1.90 \pm 0.01^{\mathrm{a}}$ & $230.71 \pm 0.34^{\mathrm{g}}$ & $31.84 \pm 0.01^{\mathrm{e}, \mathrm{f}}$ \\
\hline $\mathrm{T}_{10,0}$ & $3.94 \pm 0.01^{\mathrm{b}}$ & $12.32 \pm 0.04^{\mathrm{b}}$ & $4.46 \pm 0.03^{\mathrm{b}}$ & $14.23 \pm 0.01^{\mathrm{c}}$ & $1.90 \pm 0.01^{\mathrm{a}}$ & $264.42 \pm 0.82^{\mathrm{f}}$ & $30.42 \pm 0.03^{e}$ \\
\hline $\mathrm{T}_{10,5}$ & $3.62 \pm 0.01^{\mathrm{b}, \mathrm{c}}$ & $12.30 \pm 0.01^{\mathrm{b}}$ & $4.43 \pm 0.03^{\mathrm{b}}$ & $14.36 \pm 0.03^{c}$ & $1.88 \pm 0.01^{\mathrm{a}}$ & $283.50 \pm 0.52^{\mathrm{e}}$ & $34.65 \pm 0.02^{\mathrm{d}}$ \\
\hline $\mathrm{T}_{10,15}$ & $3.50 \pm 0.03^{\mathrm{b}, \mathrm{c}}$ & $12.28 \pm 0.01^{\mathrm{b}}$ & $4.41 \pm 0.03^{\mathrm{b}}$ & $14.53 \pm 0.01^{\mathrm{c}}$ & $1.86 \pm 0.01^{\mathrm{a}}$ & $316.36 \pm 0.65^{\mathrm{d}}$ & $40.37 \pm 0.02^{c}$ \\
\hline $\mathrm{T}_{10,25}$ & $3.36 \pm 0.02^{\mathrm{b}, \mathrm{c}}$ & $12.25 \pm 0.02^{\mathrm{b}}$ & $4.38 \pm 0.03^{\mathrm{b}}$ & $14.76 \pm 0.02^{c}$ & $1.85 \pm 0.01^{\mathrm{a}}$ & $320.23 \pm 0.67^{\mathrm{d}}$ & $41.81 \pm 0.04^{c}$ \\
\hline $\mathrm{T}_{15,0}$ & $4.38 \pm 0.03^{\mathrm{a}}$ & $13.38 \pm 0.01^{\mathrm{a}}$ & $5.72 \pm 0.03^{\mathrm{a}}$ & $12.50 \pm 0.02^{\mathrm{d}}$ & $1.88 \pm 0.01^{\mathrm{a}}$ & $335.81 \pm 0.32^{c}$ & $42.36 \pm 0.02^{c}$ \\
\hline $\mathrm{T}_{15,5}$ & $4.26 \pm 0.04^{\mathrm{a}, \mathrm{b}}$ & $13.35 \pm 0.02^{\mathrm{a}}$ & $5.69 \pm 0.03^{\mathrm{a}}$ & $12.65 \pm 0.01^{\mathrm{d}}$ & $1.86 \pm 0.01^{\mathrm{a}}$ & $372.81 \pm 0.22^{\mathrm{b}}$ & $46.32 \pm 0.03^{\mathrm{b}}$ \\
\hline $\mathrm{T}_{15,15}$ & $4.18 \pm 0.03^{\mathrm{a}, \mathrm{b}}$ & $13.34 \pm 0.01^{\mathrm{a}}$ & $5.67 \pm 0.03^{\mathrm{a}}$ & $12.82 \pm 0.03^{\mathrm{d}}$ & $1.84 \pm 0.01^{\mathrm{a}}$ & $394.61 \pm 0.63^{\mathrm{a}}$ & $51.18 \pm 0.02^{\mathrm{a}}$ \\
\hline $\mathrm{T}_{15,25}$ & $4.08 \pm 0.01^{\mathrm{a}, \mathrm{b}}$ & $13.01 \pm 0.03^{\mathrm{a}}$ & $5.65 \pm 0.03^{\mathrm{a}}$ & $13.05 \pm 0.01^{\mathrm{d}}$ & $1.83 \pm 0.01^{\mathrm{a}}$ & $378.22 \pm 0.42^{\mathrm{a}}$ & $50.65 \pm 0.01^{a}$ \\
\hline
\end{tabular}

Values are mean \pm standard deviation of three separate determinations $(\mathrm{n}=3)$. Values in the column with the same letter in superscript are not significant different from each other at $\mathrm{p} \leq 0.5$. 
$(p \leq 0.05)$. The increase in the moisture content could be due to the increasing the fiber content of biscuit samples which increases water holding capacity. These results were also reported in the previous studies which investigated the chemical, physical and sensory properties of fiber enriched biscuit samples (Ajila et al., 2008). However, the moisture content of biscuit samples enriched with roasted longan stone powder was found relatively low.

The mean values of the protein contents of the biscuits are shown in Table 2. The results indicated that as the substation ratio of roasted longan stone powder increased, protein contents significantly increased $(\mathrm{p} \leq 0.05)$ thanks to the rich protein content of longan stone.

The mean values of the crude fiber contents are shown in Table 2. Fiber contents of biscuits increased significantly $(\mathrm{p} \leq 0.05)$ as the increasing replacement ratio of longan stone powder owing to the high fiber content of the longan stones (Wisitsak et al., 2012). Sharif et al. (2009) enriched cookies with rice bran. The rice bran supplementation increased the fiber content of cookies significantly. Obafaye \& Omoba (2018) fortified biscuits with orange peel flour. Their study revealed that increasing incorporation levels of orange peel powders gradually increased the fiber content of biscuits.

The mean values of the fat content of the biscuit samples are shown in Table 2 . Fat contents of biscuits decreased significantly $(\mathrm{p} \leq 0.05)$ with the increasing substitution ratio of longan stone powder. This is due to low fat content which is particularly important for the purpose of the use of longan stones as a functional ingredient. However, the fat contents of the biscuits increased non-significantly $(\mathrm{p}>0.05)$ as the roasting degree of added longan stone powder increased.

The mean values of the ash contents of the biscuit samples are shown in Table 2. The ash contents of biscuit samples decreased non-significantly $(\mathrm{p}>0.05)$ as the increasing replacement ratio of longan stone powder.

\subsection{Antioxidant activity and total phenolic contents of biscuits}

Total phenolic content and antioxidant activity of biscuit samples are given in Table 2 . These values increased significantly $(\mathrm{p} \leq 0.05)$ as the substation ratio of the longan stone powder increased. Previous studies revealed that longan stones are important source of antioxidants and phenolic compounds (Chen et al., 2015; Jiang et al., 2013). Moreover, total phenolic contents and antioxidant activity of the biscuits increased significantly as the roasting degree of added longan stone powder increased $(\mathrm{p} \leq 0.05)$ reaching an apparent maximum at $170^{\circ} \mathrm{C}$ for $15 \mathrm{~min}$. This trend could be attributed to the formation of new phenolic compounds during roasting (Vignoli et al., 2014) and the release of phenolics from bound structures followed by chemical degradation of phenolic compounds at higher temperatures (Wijesundera et al., 2008). Thus, the fortification of biscuits with roasted longan stone powder led to a significant increase in antioxidant activity and total phenolic content. The results are comparable with the findings of Filipčev et al. (2011) who enriched biscuits with buckwheat flour and Ajibola et al. (2015) who enriched biscuits with Moringa oleifera leaves and cocoa powder.

\subsection{Color properties of biscuit samples}

$L^{*}, a^{*}, b^{*}$ values of biscuits are shown in Table 3 . As the substation ratio of longan stone powder increased, $\mathrm{L}^{*}$ and $b$ values of biscuits decreased significantly $(p \leq 0.05)$. Thus, the control biscuits had the higher lightness value than enriched biscuits with the longan stone powder. Roasted longan stones caused a significant decrease in $L^{\star}$ values $(p \leq 0.05)$. $a^{\star}$ values of biscuit samples slightly increased as the enrichment ratio of roasted longan stone powder increased. Supporting results were obtained by Ajila et al. (2008) who enriched biscuits with mango peel powder.

\subsection{Textural properties of biscuit samples}

The criteria commonly investigated to determine the quality of baked biscuits include hardness and fracturability. While hardness shows the force required to bite completely through a food material, fracturability shows the force at which the food material broke or shattered and moved away from teeth. Textural values of biscuits are shown in Table 3 . The results revealed that longan stone powder significantly affected the textural values of biscuit samples $(\mathrm{p} \leq 0.05)$. It was observed that the hardness and fracturability of biscuits increased significantly $(\mathrm{p} \leq 0.05)$ with the increasing substitution ratio of longan stone powder. It was probably due to increased fiber content of biscuit samples. On the other hand, hardness and fracturability decreased as the roasting degree of added longan stone powder increased $(\mathrm{p} \leq 0.05)$ because of the increasing fracturability of roasted longan stones due to the decreased water content and loosening of the structure causes an increase in the seed porosity and volume (Bolek \& Ozdemir, 2017). The results are supported by the observations of Srivastava et al. (2014) who enriched biscuits with dried pomegranate peel powder and Bolek (2020) who enriched the biscuits with olive stone powder.

\subsection{Sensory characteristics of the biscuit samples}

Sensory characteristics of foods significantly affect the choice of consumers. The sensory values of biscuit samples are shown in Table 4. The results demonstrated that longan stone powder significantly affected the sensory characteristics of biscuit samples $(\mathrm{p} \leq 0.05)$. The sensory values of biscuit samples decreased with addition of longan stone powder. However, these scores increased significantly with roasting of longan stone powder. Various chemical reactions, which enhance the sensory quality, occur during the roasting process. Roasting is crucial for the development of aroma and flavor. Biscuit samples enriched with longan stone powder roasted for 15 minutes at the level of $10 \%$ had the highest sensory score. As the roasting time of longan stone more increased, the sensory values of the samples decreased. Biscuits enriched with roasted longan stone powder had higher scores than control samples $(\mathrm{p} \leq 0.05)$. The roasting process increased the acceptability of addition longan stone powder. 
Table 3. Color and Textural Values of Biscuit Samples.

\begin{tabular}{|c|c|c|c|c|c|}
\hline $\begin{array}{l}\text { Substitution ratio/ } \\
\text { roasting time }\end{array}$ & $\mathrm{L}^{*}$ & $a^{*}$ & $b^{*}$ & Hardness (N) & Fracturability $(\mathrm{N})$ \\
\hline $\mathrm{T}_{5,0}^{0}$ & $60.22 \pm 0.62^{\mathrm{b}}$ & $13.05 \pm 0.02^{\mathrm{a}}$ & $30.25 \pm 0.03^{b}$ & $7.26 \pm 0.03^{c}$ & $7.82 \pm 0.03^{\mathrm{cd} d}$ \\
\hline $\mathrm{T}_{5,15}$ & $54.22 \pm 0.82^{\mathrm{d}}$ & $14.20 \pm 0.03^{\mathrm{a}}$ & $28.54 \pm 0.05^{\mathrm{bc}}$ & $6.94 \pm 0.03^{\mathrm{d}, \mathrm{e}}$ & $6.52 \pm 0.02^{e, f}$ \\
\hline $\mathrm{T}_{5,25}$ & $51.41 \pm 0.71^{\mathrm{e}}$ & $14.22 \pm 0.01^{\mathrm{a}}$ & $27.32 \pm 0.04^{c}$ & $6.77 \pm 0.02^{\mathrm{e}}$ & $6.40 \pm 0.04^{\mathrm{g}}$ \\
\hline $\mathrm{T}_{10,15}$ & $46.71 \pm 0.32^{\mathrm{g}}$ & $14.20 \pm 0.01^{\mathrm{a}}$ & $22.48 \pm 0.06^{\mathrm{d}, e}$ & $7.04 \pm 0.03^{\mathrm{d}}$ & $7.25 \pm 0.01^{\mathrm{d}, e}$ \\
\hline $\mathrm{T}_{10,25}^{115}$ & $44.23 \pm 0.42^{\mathrm{h}}$ & $14.21 \pm 0.03^{\mathrm{a}}$ & $21.37 \pm 0.03^{\mathrm{e}}$ & $6.86 \pm 0.02^{\mathrm{e}}$ & $7.07 \pm 0.02^{\mathrm{e}}$ \\
\hline $\mathrm{T}_{15,0}$ & $45.33 \pm 0.32^{\mathrm{g}, \mathrm{h}}$ & $14.20 \pm 0.02^{\mathrm{a}}$ & $17.68 \pm 0.04^{\mathrm{e}, \mathrm{f}}$ & $7.55 \pm 0.01^{\mathrm{a}}$ & $9.64 \pm 0.01^{\mathrm{a}}$ \\
\hline $\mathrm{T}_{15,5}$ & $41.81 \pm 0.52^{j}$ & $14.22 \pm 0.02^{\mathrm{a}}$ & $16.65 \pm 0.03^{g}$ & $7.35 \pm 0.02^{\mathrm{b}}$ & $8.72 \pm 0.03^{b}$ \\
\hline $\mathrm{T}_{15,15}$ & $38.61 \pm 0.63^{\mathrm{k}}$ & $14.23 \pm 0.03^{\mathrm{a}}$ & $15.22 \pm 0.05^{\mathrm{g}}$ & $7.18 \pm 0.01^{\mathrm{c}}$ & $8.34 \pm 0.01^{\mathrm{c}}$ \\
\hline
\end{tabular}

Values are mean \pm standard deviation of ten separate determinations $(n=3)$. Values in the column with the same letter in superscript are not significant different from each other at $\mathrm{p} \leq 0.5$.

Table 4. Sensory Characteristics of Biscuit Samples.

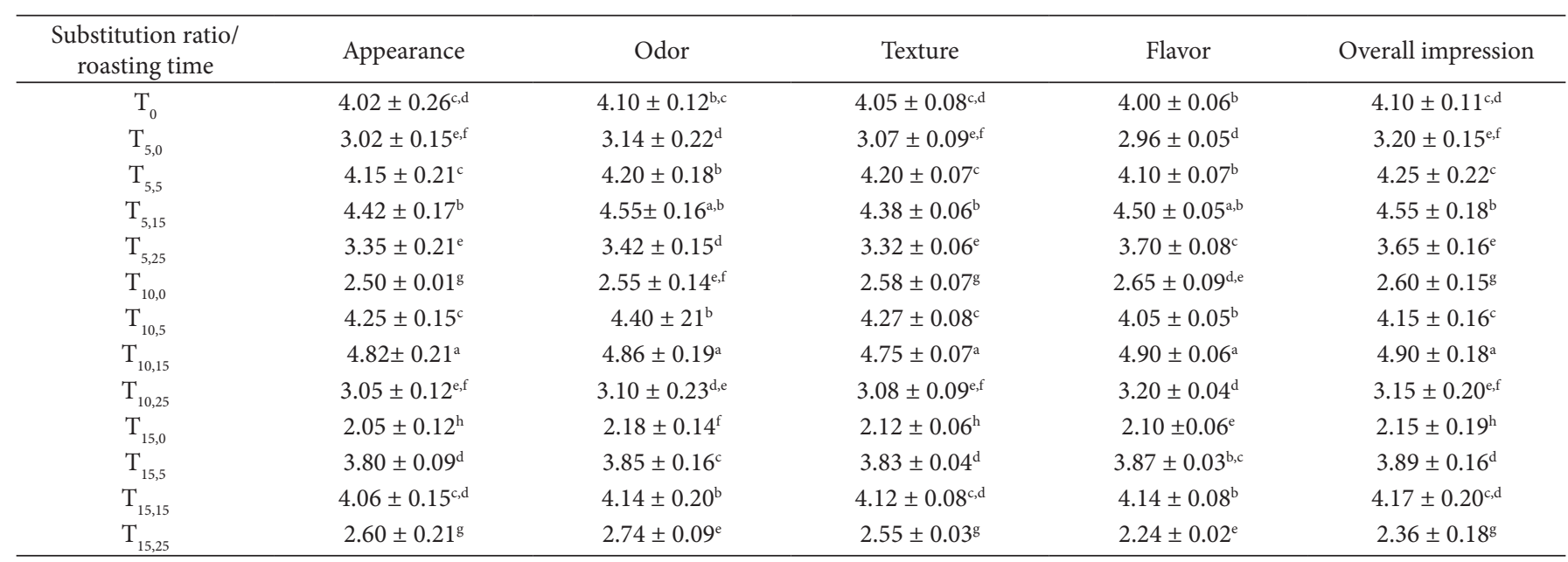

Values in the column with the same letter in superscript are not significant different from each other at $p \leq 0.5$.

\section{Conclusions}

The findings obtained in this study revealed that it is possible to prepare biscuits with high antioxidant activity, protein, and crude fiber content by the addition of longan stone powder to the biscuit formulation. The roasting process significantly affected the antioxidant activity, total phenolic content, textural and organoleptic properties of the longan stones $(\mathrm{p} \leq 0.05)$. Biscuits enriched with roasted longan stone powder took higher sensory scores than control biscuits and enriched biscuits with unroasted longan stone powder. Biscuits enriched with longan stone powder roasted for $15 \mathrm{~min}$ had the highest scores in terms of appearance, texture, flavor and overall impression. Thus, owing to their rich fiber content, antioxidant properties, nutrients and total phenolic content, longan stone could be a promising functional food ingredient. Roasting has a favorable effect on the chemical and organoleptic properties of longan stones. Fluidized bed roaster is strongly recommended for roasting of longan stones.

\section{References}

Ajibola, C. F., Oyerinde, V. O., \& Adeniyan, O. S. (2015). Physicochemical and antioxidant properties of whole-wheat biscuits incorporated with Moringa oleifera leaves and cocoa powder. Journal of Scientific Research and Reports, 7(3), 195-206. http://dx.doi.org/10.9734/ JSRR/2015/18070.

Ajila, C. M., Leelavathi, K. U. J. S., \& Prasada Rao, U. J. S. (2008). Improvement of dietary fiber content and antioxidant properties in soft dough biscuits with the incorporation of mango peel powder. Journal of Cereal Science, 48(2), 319-326. http://dx.doi.org/10.1016/j. jcs.2007.10.001.

American Association of Cereal Chemists - AACC. (2000). Approved methods of the American Association of Cereal Chemists (10th ed., Method 10-54). St Paul: AACC.

Association of Official Analytical Chemists - AOAC. (2005). Official methods of analysis (18th ed.). Arlington: AOAC.

Baljeet, S. Y., Ritika, B. Y., \& Roshan, L. Y. (2010). Studies on functional properties and incorporation of buckwheat flour for biscuit making. International Food Research Journal, 17(4), 1067-1076. 
Bolek, S. (2020). Olive stone powder: a potential source of fiber and antioxidant and its effect on the rheological characteristics of biscuit dough and quality. Innovative Food Science \& Emerging Technologies, 64, 102423. http://dx.doi.org/10.1016/j.ifset.2020.102423.

Bolek, S., \& Ozdemir, M. (2017). Optimization of roasting conditions of microwave roasted Pistacia terebinthus beans. $L W T, 86,327-336$. http://dx.doi.org/10.1016/j.lwt.2017.08.017.

Chen, J. Y., Xu, Y. J., Ge, Z. Z., Zhu, W., Xu, Z., \& Li, C. M. (2015). Structural elucidation and antioxidant activity evaluation of key phenolic compounds isolated from longan (Dimocarpus longan Lour.) seeds. Journal of Functional Foods, 17, 872-880. http://dx.doi. org/10.1016/j.jff.2015.06.028.

Choi, J. S., Kim, H. Y., Seo, W. T., Lee, J. H., \& Cho, K. M. (2012). Roasting enhances antioxidant effect of bitter melon (Momordica charantia L.) increasing in flavan-3-ol and phenolic acid contents. Food Science and Biotechnology, 21(1), 19-26. http://dx.doi.org/10.1007/ s10068-012-0003-7.

Cuendet, M., Hostettmann, K., Potterat, O., \& Dyatmiko, W. (1997). Iridoid glucosides with free radical scavenging properties from Fagraea blumei. Helvetica Chimica Acta, 80(4), 1144-1152. http:// dx.doi.org/10.1002/hlca.19970800411.

De Maria, C. A. B., Trugo, L. C., Aqino, F. A. No., Moreira, R. F. A., \& Alviano, C. S. (1996). Composition of green coffee water-soluble fractions and identification of volatiles formed during roasting. Food Chemistry, 55(3), 203-207. http://dx.doi.org/10.1016/03088146(95)00104-2.

Filipčev, B., Šimurina, O., Sakač, M., Sedej, I., Jovanov, P., Pestorić, M., \& Bodroža-Solarov, M. (2011). Feasibility of use of buckwheat flour as an ingredient in ginger nut biscuit formulation. Food Chemistry, 125(1), 164-170. http://dx.doi.org/10.1016/j.foodchem.2010.08.055.

International Organization for Standardization - ISO. (2007). ISO 8589: sensory analysis: general guidance for the design of test rooms. Geneva: ISO.

International Organization for Standardization - ISO. (2012). ISO 8586: sensory analysis: general guidelines for the selection, training and monitoring of selected assessors and expert sensory assessors. Geneva: ISO.

Jiang, G., Wen, L., Chen, F., Wu, F., Lin, S., Yang, B., \& Jiang, Y. (2013). Structural characteristics and antioxidant activities of polysaccharides from longan seed. Carbohydrate Polymers, 92(1), 758-764. http:// dx.doi.org/10.1016/j.carbpol.2012.09.079. PMid:23218364.

Li, N. H., Wu, P. P., \& Huang, R. Q. (2012). Analysis of nutrition content in longan seeds. Advanced Materials Research, 554-556, 1025-1028. http://dx.doi.org/10.4028/www.scientific.net/AMR.554-556.1025.

Lin, D., Xiao, M., Zhao, J., Li, Z., Xing, B., Li, X., Kong, M., Li, L., Zhang, Q., Liu, Y., Chen, H., Qin, W., Wu, H., \& Chen, S. (2016). An overview of plant phenolic compounds and their importance in human nutrition and management of type 2 diabetes. Molecules, 21(10), 1374. http://dx.doi.org/10.3390/molecules21101374. PMid:27754463.

Obafaye, R. O., \& Omoba, O. S. (2018). Orange peel flour: a potential source of antioxidant and dietary fiber in pearl-millet biscuit. Journal of Food Biochemistry, 42(4), e12523. http://dx.doi.org/10.1111/ jfbc. 12523.

Oliveira, L. S., Franca, A. S., Mendonça, J. C., \& Barros-Junior, M. C. (2006). Proximate composition and fatty acids profile of green and roasted defective coffee beans. Lebensmittel-Wissenschaft + Technologie, 39(3), 235-239. http://dx.doi.org/10.1016/j.lwt.2005.01.011.
Priftis, A., Stagos, D., Konstantinopoulos, K., Tsitsimpikou, C., Spandidos, D. A., Tsatsakis, A. M., Tzatzarakis, M. N., \& Kouretas, D. (2015). Comparison of antioxidant activity between green and roasted coffee beans using molecular methods. Molecular Medicine Reports, 12(5), 7293-7302. http://dx.doi.org/10.3892/mmr.2015.4377. PMid:26458565.

Rangkadilok, N., Sitthimonchai, S., Worasuttayangkurn, L., Mahidol, C., Ruchirawat, M., \& Satayavivad, J. (2007). Evaluation of free radical scavenging and antityrosinase activities of standardized longan fruit extract. Food and Chemical Toxicology, 45(2), 328-336. http:// dx.doi.org/10.1016/j.fct.2006.08.022. PMid:17049706.

SAS Institute Inc. (1999). Proprietary software. Release 8.2 (TS2MO). Cary: SAS.

Sharif, M. K., Butt, M. S., Anjum, F. M., \& Nawaz, H. (2009). Preparation of fiber and mineral enriched defatted rice bran supplemented cookies. Pakistan Journal of Nutrition, 8(5), 571-577. http://dx.doi. org/10.3923/pjn.2009.571.577.

Shi, S., Wang, W., Liu, L., Wu, S., Wei, Y., \& Li, W. (2013). Effect of chitosan/nano-silica coating on the physicochemical characteristics of longan fruit under ambient temperature. Journal of Food Engineering, 118(1), 125-131. http://dx.doi.org/10.1016/j.jfoodeng.2013.03.029.

Slinkard, K., \& Singleton, V. L. (1977). Total phenol analysis: automation and comparison with manual methods. American Journal of Enology and Viticulture, 28(1), 49-55.

Soong, Y. Y., \& Barlow, P. J. (2006). Quantification of gallic acid and ellagic acid from longan (Dimocarpus longan Lour.) seed and mango (Mangifera indica L.) kernel and their effects on antioxidant activity. Food Chemistry, 97(3), 524-530. http://dx.doi.org/10.1016/j. foodchem.2005.05.033.

Srivastava, P., Indrani, D., \& Singh, R. P. (2014). Effect of dried pomegranate (Punica granatum) peel powder (DPPP) on textural, organoleptic and nutritional characteristics of biscuits. International Journal of Food Sciences and Nutrition, 65(7), 827-833. http://dx.doi.org/10.3 109/09637486.2014.937797. PMid:25019979.

Valiente, C., Esteban, R. M., Mollá, E., \& López-Andréu, F. J. (1994). Roasting effects on dietary fiber composition of cocoa beans. Journal of Food Science, 59(1), 123-124. http://dx.doi.org/10.1111/j.1365-2621.1994. tb06914.x.

Vignoli, J. A., Viegas, M. C., Bassoli, D. G., \& de Toledo Benassi, M. (2014). Roasting process affects differently the bioactive compounds and the antioxidant activity of arabica and robusta coffees. Food Research International, 61, 279-285. http://dx.doi.org/10.1016/j. foodres.2013.06.006.

Wijesundera, C., Ceccato, C., Fagan, P., \& Shen, Z. (2008). Seed roasting improves the oxidative stability of canola (B. napus) and mustard (B. juncea) seed oils. European Journal of Lipid Science and Technology, 110(4), 360-367. http://dx.doi.org/10.1002/ejlt.200700214.

Wisitsak, P., Nimkamnerd, J., Thitipramote, N., Saewan, N., Chaiwut, P., \& Pintathong, P. (2012). Comparison the bioactive compounds and their activities between longan and litchi seeds extracts. In Proceedings of the $1^{\text {st }}$ Mae Fah Luang University International Conference. Thailand.

Yang, B., Jiang, Y., Shi, J., Chen, F., \& Ashraf, M. (2011). Extraction and pharmacological properties of bioactive compounds from longan (Dimocarpus longan Lour.) fruit: a review. Food Research International, 44(7), 1837-1842. http://dx.doi.org/10.1016/j.foodres.2010.10.019.

Zheng, G., Xu, L., Wu, P., Xie, H., Jiang, Y., Chen, F., \& Wei, X. (2009). Polyphenols from longan seeds and their radical-scavenging activity. Food Chemistry, 116(2), 433-436. http://dx.doi.org/10.1016/j. foodchem.2009.02.059. 